\title{
Erroneous identification of the mussel, Mytilus galloprovincialis (Lamarck 1819) as the specie, Mytilus chilensis (Hupe 1854) in the Bay of Concepcion, Chile
}

\author{
Identificación errónea del mejillón, Mytilus galloprovincialis (Lamarck 1819) como la \\ especie, Mytilus chilensis (Hupe 1854) en la Bahía de Concepción, Chile
}

\author{
Eduardo Tarifeño $0^{1 *}$, Ricardo Galleguillos ${ }^{2}$, Alejandra Llanos-Rivera ${ }^{3}$, Daniel Arriagada ${ }^{1}$, Sandra $^{2}$ \\ Ferrada ${ }^{2,4}$, Cristian B. Canales-Aguirre ${ }^{2,4}$ and Maritza Seguel ${ }^{2}$
}

\begin{abstract}
${ }^{1}$ Grupo I\&D ProMytilus-UdeC, Departamento de Zoología, Facultad de Ciencias Naturales y Oceanografía. Universidad de Concepción, Casilla 160-C, Concepción, Chile.

${ }^{2}$ Laboratorio de Genética y Acuicultura, Departamento de Oceanografía Facultad de Ciencias Naturales y Oceanografía. Universidad de Concepción, Casilla 160-C, Concepción, Chile.

${ }^{3}$ Unidad de Biotecnología Marina y Acuicultura, Facultad de Ciencias Naturales y Oceanografía. Universidad de Concepción, Casilla 160-C, Concepción, Chile.

${ }^{4}$ Programa de Doctorado en Sistemática y Biodiversidad, Facultad de Ciencias Naturales y Oceanografía. Universidad de Concepción, Casilla 160-C, Concepción, Chile.

*E-mail: etarifen@udec.cl
\end{abstract}

\begin{abstract}
This communication informs that presence of the Chilean mussel, Mytilus chilensis (Hupe 1854) in the coast of the Bay of Concepcion (Chile) reported in the scientific literature is an erroneous identification, being Mytilus galloprovincialis (Lamarck 1819) the right species.
\end{abstract}

\section{RESUMEN}

Esta comunicación informa que la presencia de Mytilus chilensis (Hupe 1854) citada en la literatura científica para la costa de la Bahía de Concepción (Chile) no es correcta, siendo Mytilus galloprovincialis (Lamarck 1819) la identificación taxonómica válida.

\begin{abstract}
The increasing interest to carry out mussel farming in the coasts of the Gulf of Arauco and Bay of Concepcion (Central Chile) requires knowing exactly what species of mussels are present in this coastal zone because aquaculture activity in this coastal region can be done only with organisms living in the zone. In the literature on the bivalves inhabiting the intertidal zone of this region, Aldea \& Valdovinos (2005) mention to the Chilean mussel, Mytilus chilensis (Hupe 1854) in sampling carried out in 2001, as naturally present in the rocky shore of: i) Punta Parra Cove, Cocholgüe Cove and Port of Talcahuano within the Bay of Concepcion, ii) mouth of the Biobío river, iii) Tubul Cove and Punta Lavapié Cove inside the Gulf of Arauco. These localities represent a geographic range from $\mathrm{S} 36^{\circ} 38^{\prime} 43^{\prime \prime}$ to $\mathrm{S} 37^{\circ} 09^{\prime} 01^{\prime \prime}$.
\end{abstract}

However, the taxonomic identification made by these authors, is erroneous. The correct species corresponds to the mussel, Mytilus galloprovincialis (Lamarck 1819) with local name of "choro araucano" in Chile. This mussel species shows a world-wide distribution (Westfall \& Gardner 2010) and Castilla et al. (2005) indicated its presence at the Chiloe Island at Southern Chile and at Bay of Coliumo (Central Chile). The identification mistake was verified by examining the same mussel valves deposited by Aldea \& Valdovinos (2005) in the Museum of Zoology of the Universidad de Concepción with the accessing code UCCC 29016 (Figure 1, Left). The morphologic comparison of the mussel shells studied by Aldea \& Valdovinos (2005) with shells of M. chilensis and $M$. galloprovincialis validated genetically following the protocol of Santaclara et al. (2006) and deposited with accessing codes UCCC 1208 (Figure 1, Center) and UCCC 35932 (Figure 1, Right), respectively, shows the identification mistake done by these authors. 
Morphological differences among shells of Mytilus edulis, Mytilus galloprovincialis and Mytilus trossulus deposited at the British Museum of Natural History of London by McDonald et al. (1991) with accessing number 1299, 2309 and 2244, respectively, are showed in Figure 2 for comparison purposes. On base upon these materials, collected at Magdalen Island (Quebec, Canada), Posjet Bay (U.S.S.R) and Magadan (U.S.S.R), respectively, McDonald et al. (1991) named the "Mytilus Complex" considered as a standard on the Mytilus taxonomy.

To accurately verify the presence of $M$. chilensis in the same intertidal points worked in 2001 by Aldea \& Valdovinos (2005), new mussel samplings were carried out by us on October of 2011 in the rocky shore intertidal zone within the Bay of Concepcion, at the localities of Parra Point Cove, Bellavista Beach and Cocholgüe Cove. The careful search for Mytilus spp. naturally settled on these intertidal points revealed only the presence of $M$. galloprovincialis forming

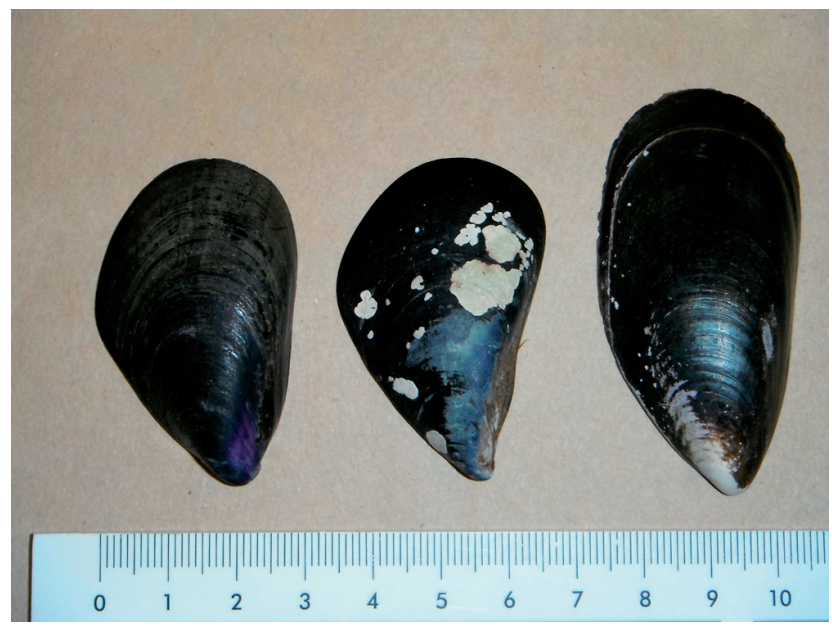

FIGURE 1. Left: Mytilus chilensis, identified by Aldea \& Valdovinos (2205) (UCCC 29061); Center: Mytilus galloprovincialis (UCCC 35932); Right: Mytilus chilensis (UCCC1208).

Figura 1. Izquierda: Mytilus chilensis, identificado por Aldea \& Valdovinos(2205)(UCCC29061); Centro:Mytilus galloprovincialis (UCCC 35932); Derecha: Mytilus chilensis (UCCC1208). either isolated patches or single specimens coexisting with the other common intertidal mussel, Perumytilus purpuratus (Lamarck 1819). The in situ identification of $M$. galloprovincialis was endorsed later on in the Laboratory Genetic and Aquaculture of the Universidad of Concepción, applying the protocol of PCR-RFLP developed by Santaclara et al. (2006). This clear-cut assay genetic method is based on the amplification of the genes of the polyphenolic proteins that made the byssus of theses bivalves, using the genetic markers Me15 and Me16 described earlier by Inoue et al. (1995). These genetic markers generate a fragment of 126 pairs of bases in M. chilensis and M. galloprovincialis, which are digested with endonuclease Aci I, according to Santaclara et al. (2006). The restriction site of the enzyme is only present in the DNA of M. galloprovincialis generating then two new fragments of 57 and to 69 pairs of bases but this result is not exhibited by $M$. chilensis, species that conserves the band of $126 \mathrm{pb}$ once digested with Aci I. (Figure 3).

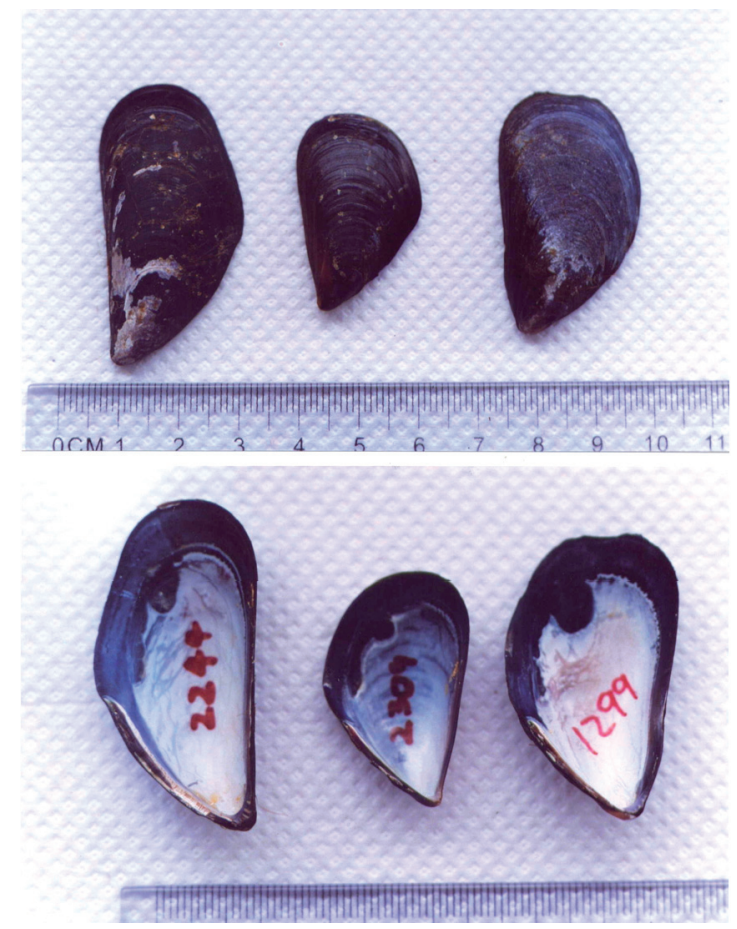

Figure 2. Mussel valves deposited at the British Museum of Natural History (London) by MacDonald et al. (1991).Keys: 2244, Mytilus trossulus; 2309, Mytilus galloprovincialis; 1299 , Mytilus edulis. Upper row, outside view of right valve; bottom row, inside view of the right valve.

Figura 2. Valvas de mitilidos depositados por MacDonald et al. (1991) en el Museo de Historia Natural de Londres. Claves: 2244, Mytilus trossulus; 2309, Mytilus galloprovincialis; 1299, Mytilus edulis. Fila superior, vista externa de valva derecha; fila inferior, vista interna de valva derecha. 


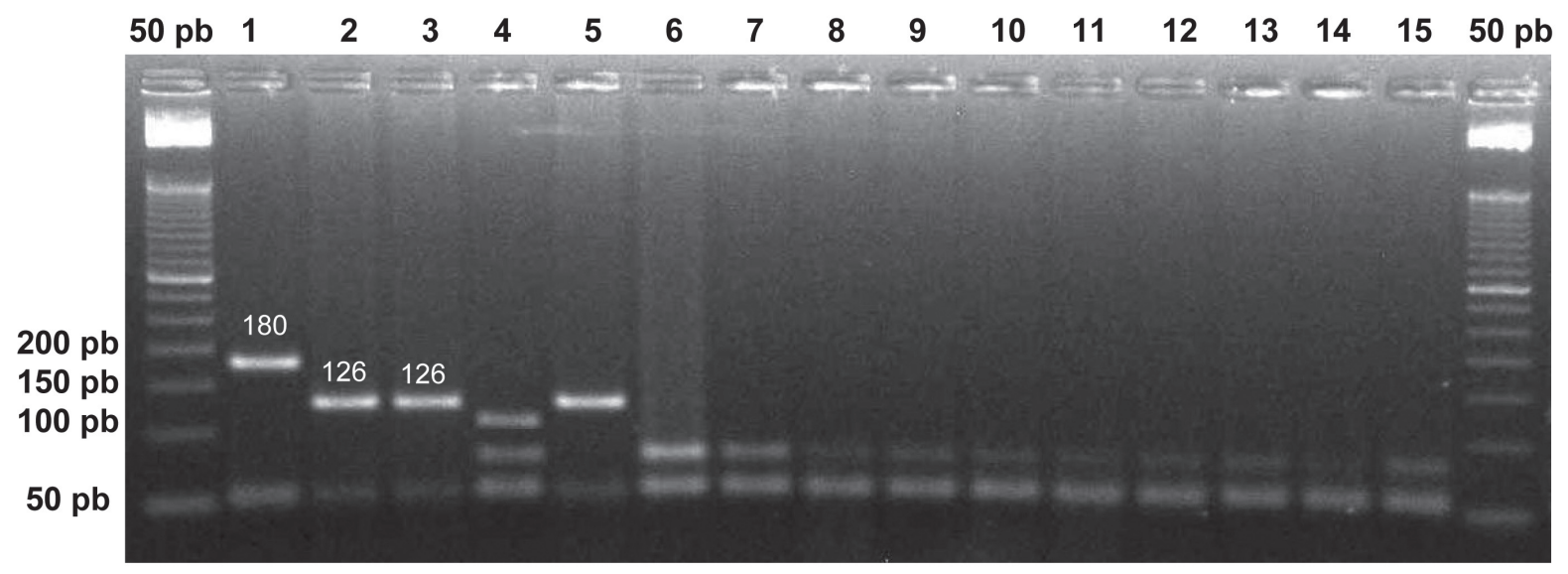

FIGURE 3. PCR-RFLP of the polyphenolic protein gen with Aci I enzyme, obtained from Mytilus spp. samples. Line 50 bp: DNA ladder, Invitrogen; 1, PCR from M. edulis; 2, PCR from M. chilensis; 3, PCR from M. galloprovincialis; 4, RFLP from M. edulis; 5, RFLP from M. chilensis; 6; RFLP from M. galloprovincialis; 7-9 RFLP from M. galloprovincialis collected at Punta de Parra Cove; 10-12, RFLP form M. galloprovincialis collected at Bellavista Cove; 13-15 RFLP from M. galloprovincialis collected at Cocholgue Cove.

Figura 3. Perfil de Restricción (PCR-RFLP) del gen de la proteína polifenólica con la enzima Aci I, obtenidos con ejemplares de Mytilus spp. Linea 50 pb: Marcador de Peso Molecular (50 bp DNA ladder, Invitrogen); 1, producto de PCR de M. edulis; 2, producto de PCR de M. chilensis; 3, producto de PCR de M. galloprovincialis; 4, RFLP de M. edulis con la enzima Aci I; 5, RFLP de M. chilensis con la enzima Aci I; 6, RFLP de M. galloprovincialis con la enzima Aci I; 7-9 RFLP de ejemplares de M. galloprovincialis de Punta de Parra; 10-12, RFLP de ejemplares de M. galloprovincialis de Bellavista, Tomé; 13-15 RFLP de ejemplares de M. galloprovincialis de Cocholgue.

The first mention of the presence of M. galloprovincialis in Chilean coasts, specifically Dichato (Bay of Coliumo, Chile) was made by Daguin \& Borsa (2000) applying molecular markers. Later on, Ruiz et al. (2005) and Toro et al. (2005) ratified this reference. Castilla et al. (2005) cited M. galloprovincialis as an exotic invasive species to Chile with presence at Castro and Yaldad (Chiloe Island; Southern Chile) and Dichato (Bay of Coliumo, Central Chile) following Toro et al. (1998), Daguin \& Borsa (2000) and Hilbish et al. (2000). The manuscript of Castilla et al. (2005) was sent for publication on 2001 indicating that the main focus of distribution of M. galloprovincialis was the mussel farms at Chiloe Island but without evidence of local natural beds of this mussel species. Daguin (2000) and Daguin \& Borsa (2000) based on nuclear DNA markers, pointed out that $M$. galloprovincialis could be introduced to Chile from the Mediterranean. However, it has to be noted that until Santaclara et al. (2006), adequate genetic molecular markers were not standardized to accurately separate M. chilensis from M. galloprovincialis. By this reason, samples of $M$. chilensis could be recognized as $M$. galloprovincialis in the studies carried out by Toro et al. (1998), Hilbish et al. (2000) and Daguin \& Borsa (2000). Recently, Borsa et al. (2012) discuss the taxonomic status of M. chilensis pointing out that different Mytilus species might have been included under " $M$. chilensis" proposing that the native Chilean smooth-shelled Mytilus, should be assigned subspecific rank and named $M$. edulis platensis d'Orbigny
1846 (Borsa et al. 2012). The point that whether M. chilensis is an accepted species among the Mytilus complex, together with its geographical distribution along the Chilean coasts, needs to be clarified as soon as possible, since the massive aquaculture activities on this marine resource at southern Chilean coasts.

The presence of the mussel M. galloprovincialis at the coasts of the Gulf of Arauco, Bay of Concepcion and Bay of Coliumo was long time missed by artisanal fishermen and ecologists because its similar shell shape, size and shell color with juveniles of the mussel Choromytilus chorus (Molina 1782), a very abundant subtidal mussel in these coastal areas. The most notorious differences between both species, are the number and size of teeth located on the hinge line of the shell beneath the ligament, being only 1-2 and large on Ch. Chorus and more than 5 and small in M. galloprovincialis; and the color of the female gonad that it is dark-brown in Ch. Chorus and yellow-orange in $M$. galloprovincialis. In addition, samples of mussels collected from a long-line system for culturing the northern scallop, Chlamys purpuratus at Tongoy Bay $\left(30^{\circ} 15^{\prime} \mathrm{S}\right)$ and from a $M$. chilensis farm at Chiloé Island $\left(41^{\circ} \mathrm{S}\right)$ send to us for taxonomic identification, were genetically identified as $M$. galloprovincialis (Figure 4).

On the other hand, Hupé (1854) mentions and describes the mussel species, Mytilus chorus, Mytilus chilensis, Mytilus 
dactyliformis, Mytilus magellanicus, Mytilus orbignyanus, Mytilus granulatus, Mytilus ovalis and Mytilus scalprum at the Chilean coast. From the description given by Hupé (1854) and the details in the scientific drawings in the Plate 5 (Figure 5) it could be concluded that Hupé (1854) citation of M. chorus corresponds to Choromytilus chorus (named by Hupé "as a typical mussel from Concepcion Bay"); meanwhile, $M$. chilensis (Plate 5, fig. 4) is the actual species M. chilensis applying Santaclara et al. (2006) protocol; and $M$. dactyliformis (Plate 5, figs. 6, 6A) corresponds to Semimytilus algosus (Gould 1859). However, it is remarkable that $M$. orbignyanus, cited by Hupé (1854) as living at Coquimbo coasts $\left(30^{\circ} \mathrm{S}\right)$ shows quite similar shell-shape to the actual M. galloprovincialis. Furthermore, the figures 4, 5 and $5 \mathrm{a}$ in the Plate 5 of Hupé work (1854) evidence the same morphological differences that can be observed today between M. chilensis and M. galloprovincialis.

Since Aldea \& Valdovinos (2005) are frequently cited as a confident source that $M$. chilensis is living at the Bay of Concepcion, it was necessary to clarify the erroneous identification of $M$. chilensis made by these authors.
However, it could be possible that in the near future, natural beds of $M$. chilensis could be found in the coastal zone of Trana and Llico Coves (inside Gulf of Arauco), Coliumo, Dichato and Burca Coves (inside Bay of Coliumo) established from commercial aquaculture activities started with $M$. chilensis seeds massively brought from Chiloé Island (Southern Chile) since 2009. All these commercial mussel farms were strongly affected by the $27 /$ February tsunami, with the growing systems entangled on the beaches, and the mussels fully dispersed on the sandy and rocky bottoms. Actually, there are high concerns that $M$. chilensis seeds transported from the Chiloé Island to support mussel farming at Gulf of Arauco, Bay of Concepcion and Bay of Coliumo can be a biological hazard to this marine environment since transported collectors with mussel seeds could be contaminated with dinoflagellates and diatoms that produce toxic red tides that commonly occurs at the Chiloé Island, but so far have been not reported to the coastal waters of Gulf of Arauco, Bay of Concepcion and Bay of Coliumo.

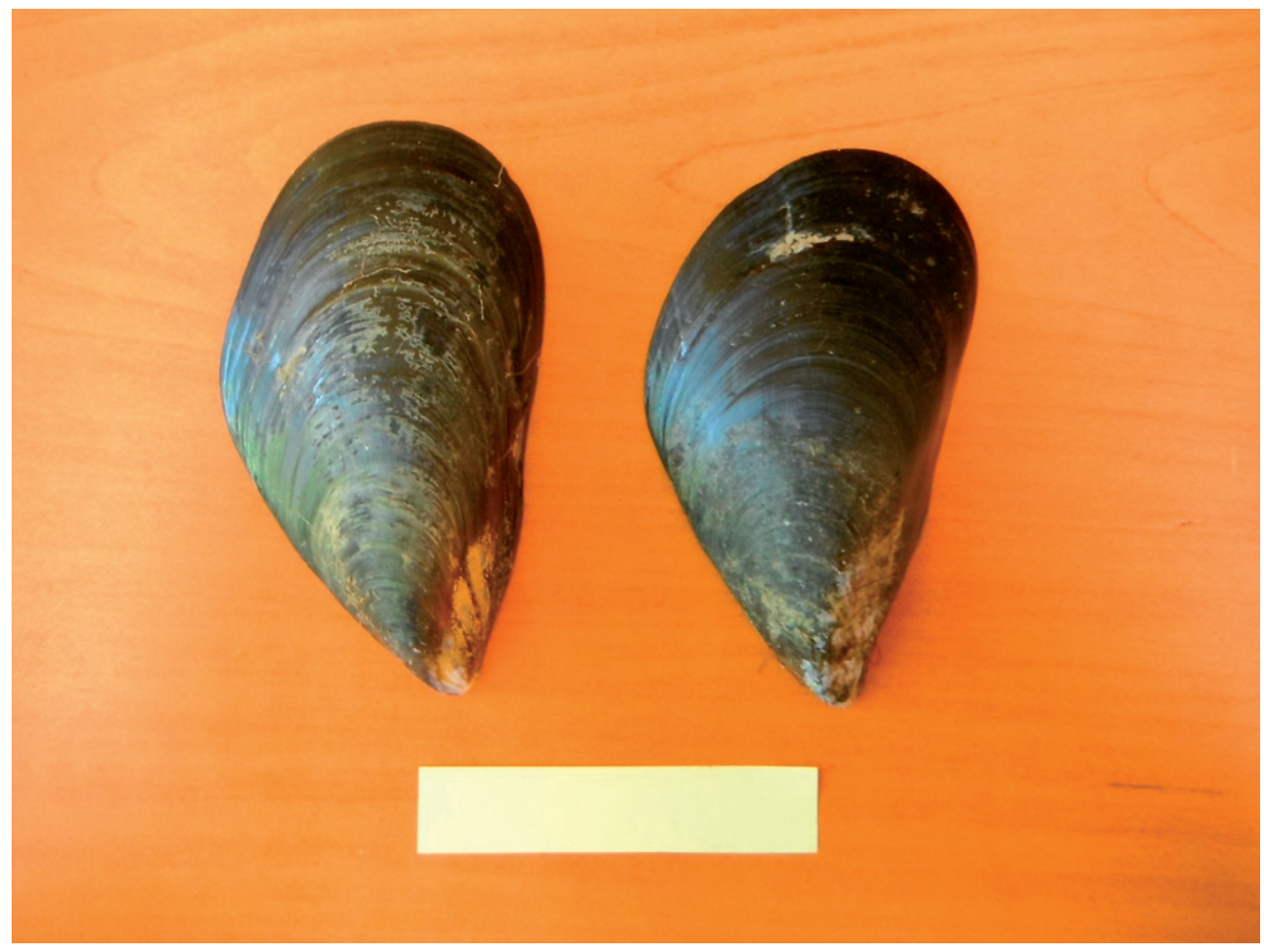

Figure 4. Righ valves of M. galloprovincialis collected at Bay of Tongoy (left) and Chiloe Island (right). Bar $=5 \mathrm{~cm}$.

Figura 4. Valvas derechas de M. galloprovincialis colectadas en Bahía de Tongoy y en Isla de Chiloé. Barra $=5 \mathrm{~cm}$. 
Erroneous Identification of Mytilus galloprovincialis: EDUARDO TARIFEÑO ET AL.

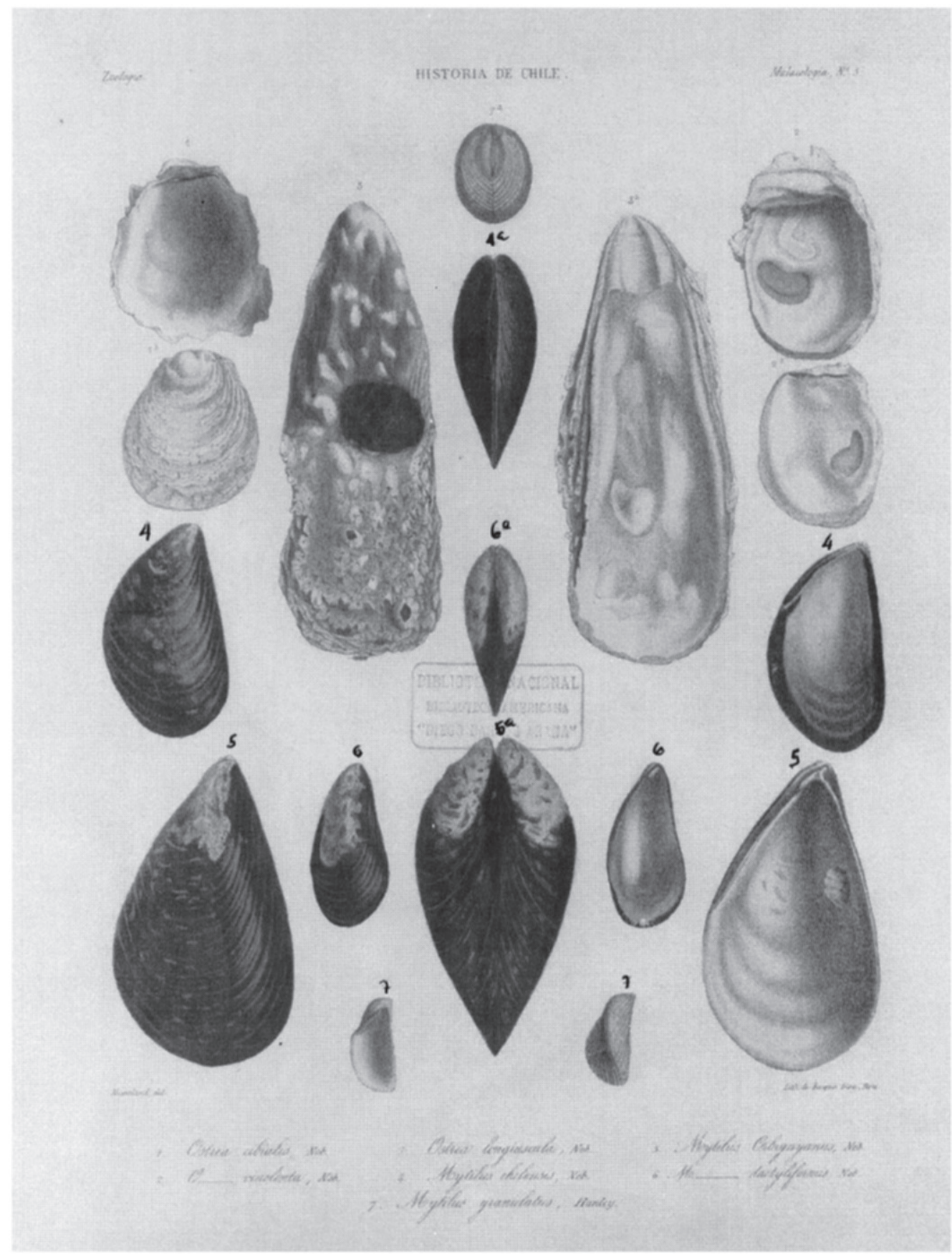

Figure 5. Plate 5 in Gay (1854) showing the different species of bivalves described by Hupe (1854). 4: Mytilus chilensis; 5: Mytilus orbignyanus; 6: Mytilus dactyliformis; 7: Mytilus granulatus.

Figura 5. Lámina 5 en Gay (1854) mostrando las diferentes especies de bivalvos descritos por Hupe (1854). 4: Mytilus chilensis; 5: Mytilus orbignyanus; 6: Mytilus dactyliformis; 7: Mytilus granulatus. 


\section{ACKNOWLEDGMENTS}

S. Ferrada and C. B. Canales-Aguirre are students in the Doctoral Program in Systematics and Biodiversity and were supported by UdeC Doctoral Fellowship. This work was funded by projects FONDEF D03I-1095 and INNOVACORFO 10CREC8535.

\section{REFERENCES}

Aldea, C. \& Valdovinos, C. 2005. Moluscos del intermareal rocoso del centro-sur de Chile $\left(36^{\circ}-38^{\circ} \mathrm{S}\right)$ : Taxonomía y claves de identificación. Gayana 69(2):364-396.

Borsa, P., Rolland, V. \& Danguin-Thiebaut, C. 2012. Genetic and taxonomy of the Chilean smooth-shelled mussels, Mytilus spp. (Bivalvia: Mytilidae). Compte Rendus Biologies 335: 51-61.

Castilla, J.C., Uribe, M., Bahamondes, N., Clarke, M., Desqueyroux, R., Kong, I., Moyano, H., Rozbaczylo, N., Santelices, B., Valdovinos, C. \& Zavala, P. 2005. Down under the southeastern Pacific: a survey of marine exotic invasive species to Chile. Biological Invasions 7:213-232.

Daguin, C. \& P. Borsa. 2000. Genetic relationship of Mytilus galloprovincialis Lamarck population worldwide: evidences from nuclear-DNA markers. Geological Society, London, Special publication, 177: 389-397.

Hupe, L. 1854. Moluscos de Chile. In: C. Gay (ed.). Historia Física y Política de Chile. Zool. 8:1-500. Atlas II, lám. 5, figs. 4 y 5. Interspecific variations in adhesive protein sequences of Mytilus edulis, M. galloprovincialis and Mytilus trossulus. Biological Bulletin 189 (3): 370-375.

Mcdonald, J. H., Seed, R. \& Koenn, R. K. 1991. Allozymes and morphometric characters of three species of Mytilus in the northern and southern hemispheres. Marine Biology 111: 323-333.

Ruiz, M., Tarifeño, E., Llanos-Rivera, A., Padget, C. \& Campos, B. 2008. Temperature effect in the embryonic and larval development of the mussel, Mytilus galloprovincialis (Lamarck, 1819). Revista de Biología Marina y Oceanografía 43: 51-61.

Santaclara, F.J., Espiñeira, M., Cabado, A.G., Aldaroso, A., Gonzalez-Lavin, N. \& J.M. Vieites. 2006. Development of a method for the genetic identification of mussel species belonging to Mytilus, Perna, Aulacomya, and other genera. Journal of Agricultural and Food Chemistry 54: 86618470.

Toro, J., Ojeda, L., Vergara, A., Castro, G. \& Alcapan, 1. 2005. Molecular characterization of the Chilean blue mussel (Mytilus chilensis Hupe 1854) demonstrates evidence for the occurrence of Mytilus galloprovincialis in southern Chile. Journal of Shellfish Research 24(4):1117-1121.

Westfall, K., \& Gardner, J. 2010. Genetic diversity of Southern hemisphere blue mussels (Bivalvia: Mytilidae) and the identification of non-indigenous taxa. Biological Journal of the Linnaean Society 101: 989-909.

Recibido: 21.06 .12

Aceptado: 03.10.12 